\title{
SISTEM PENENTU KARYAWAN TERBAIK DENGAN METODE FUZZY MAMDANI MENGGUNAKAN RADIO FREQUENCY IDENTIFICATION (RFID) SEBAGAI PRESENSI
}

\author{
Muhammad Ariq Ihsan, Joseph Dedy Irawan, Karina Auliasari \\ Program Studi Teknik Informatika S1, Fakultas Teknologi Industri \\ Institut Teknologi Nasional Malang, Jalan Raya Karanglo km 2 Malang, Indonesia \\ Ariqihsan839@gmail.com
}

\begin{abstract}
ABSTRAK
Manajemen presensi kehadiran yang kian berkembang saat ini perlu memanfaatkan kehadiran teknologi informasi, pasalnya, perkembangan teknologi yang semakin hari semakin pesat dapat menghadirkan informasi maupun mengolah informasi secara realtime. . Untuk itu diperlukan pengelolahan informasi absensi yang mumpuni dan dapat memantau kehadiran para pekerja secara realtime dan mudah.

Pada pembuatan aplikasi ini akan dikembangkan system penentu karyawan terbaik dengan metode fuzzy Mamdani menggunakan radio frequency identification (rfid) sebagai presensi. Penggunaan rfid dapat mempermudah para karyawan dalam melakukan absensi kehadiran. dengan adanya sistem ini dapat membantu perusahaan dalam memantau kehadiran para karyawan secara efisien dan terkomputerisasi sehingga dapat menghindari kecurangan atau manipulasi absensi dan dapat membantu perusahaan dalam menentukan karyawan terbaik menggunakan data kehadiran karyawan.

Karena itu, teknologi RFID menjadi pilihan penulis untuk mengatasi masalah dalam sistem absensi karena dinilai lebih mudah dan hemat waktu bagi karyawan untuk dapat melakukan absensi sebelum memulai pekerjaannya. Karena yang biasanya terjadi para karyawan diharuskan untuk melakukan absensi masuk terlebih dahulu sebelum memulai pekerjaan
\end{abstract}

Kata Kunci : penentu karyawan, presensi karyawan, rfid

\section{PENDAHULUAN}

Dunia usaha saat ini sangat memerlukan tingkat kedisiplinan karyawan agar proses pekerjaan dapat berlangsung sesuai dengan jadwal yang sudah di tentukan. Permasalahan yang biasanya sering timbul dalam dunia usaha adalah banyaknya para pekerja yang sering terlambat untuk bekerja. Dalam kondisi tersebutlah dibutuhkan sistem yang dapat membaca kehadiran para pekerja yang mumpuni dan bebas dari kecurangan sehingga perusahaan mungkin bisa mengukur tingkat kehadiran para karyawan sebagai sebuah penilaian prestasi dalam perushaan.

Penilaian prestasi kerja karyawan sebagai alat yang berguna untuk mengevaluasi kerja para karyawan dan memotivasi karyawan untuk lebih giat dan rajin dalam bekerja sesuai dengan standar dan aturan yang telah di tetapkan dalam sebuah perusahaan. Perusahaan yang memperkerjakan pegawai juga dapat memberikan reward kepada karyawan yang kinerjanya di atas rata-rata. Maka dari itu penulis ingin membuat system penentu karyawan terbaik dengan metode fuzzy Mamdani menggunakan Radio Frequency Identification (RFID) sebagai presensi. Jadi para pegawai dapat melakukan absensi terlebih dahulu dan absensi pulang menggunakan rfid yang terintegrasi dengan system penentu karyawan terbaik. Digunakannya RFID dikarenakan proses pertukaran data RFID sangat cepat dan penggunaannya cukup simpel dan mudah. Data kehadiran dari RFID kemudian di kelola dan dapat di monitoring menggunakan media website.
Digunakannya website sebagai media monitoring dikarenakan proses penggunaanya cukup mudah dibandingkan perangkat desktop dan dapat digunakan dimana saja serta admin dan pemilik perusahaan juga bisa melakukan monitoring kehadiran para pegawai dengan mudah.

Untuk itulah akan dikembangkan system penentu karyawan terbaik dengan metode fuzzy Mamdani menggunakan rfid dan akan ditampilkan secara visual pada fitur monitoring sehingga ketepatan waktu kehadiran dapat dimonitoring dengan baik serta dapat menentukan karyawan terbaik agar bisa memotivasi pekerja yang lain untuk lebih giat lagi.

\section{TINJAUAN PUSTAKA}

\subsection{Penelitian Terdahulu}

Ditahun 2013 Aditia mengembangkan aplikasi RFID untuk system presensi mahasiswa di universitas brawijaya berbasis protocol internet. Aplikasi ini menggunakan RFID modul ACM 120s yang bekerja pada frekuensi 13,65 Mhz dan Mikrokontroller AtMega 328 sebagai pusat system pembaca presensi. Mikrokontroller Atmega 328 kemudian mengirimkan data presensi ke server melalui jaringan internet menggunakan Modul WIZ812MJ. Sistem komunikasi yang digunakan adalah protocol TCP/IP. Kemudian data presensi dikirim dan di proses dan kemudian di rekap di server. Hasilnya alat ini mampu melakukan presensi dengan rata-rata waktu yang dibutuhkan 
proses pembacaan hingga menerima respon dari server sebesar $40 \mathrm{~ms}$ [1].

Ditahun 2015 Ihsan merancang aplikasi system absensi mahasiswa menggunakan sidik jari pada universitas putra Indonesia "YPTK" Padang. Penelitian ini menggunakan sidik jari untuk system presensi mahasiswa. Tak berbeda jauh dengan RFID, system ini juga memerlukan record data terlebih dahulu menggunakan data sidik jari. Aplikasi ini dibuat karena system absensi manual dirasa kurang efektif karena peluang manipulasi absensi bisa saja dilakukan oleh mahasiswa. Penelitian ini menggunakan model waterfall, karena memang diagram tahapan prosesnya mirip seperti air terjun yang bertingkat. Penelitian ini menggunakan system biometric yaitu fingerprint. Dari hasil penelitian tersebut diketahui bahwa presensi menggunakan fingerprint lebih cepat dibandingkan dengan manual [2].

Ditahun 2016 Amali dan kawan-kawan merancang system penggajian guru menggunakan RFID. Pada penelitian ini menggunakan RFID reader dan RFID Transponder Pasif (Card). Pada penelitian ini menerapkan batas toleransi keterlambatan 30 menit dan apabila melewati 30 menit maka akan dilakukan pemotongan gaji sebesar Rp. 5.000, jika tidak masuk aka nada pemotongan Rp. 10.000. pengujian menggunakan ktp yang di dekatkan ke RFID reader dan akan disimpan ke dalam database [3].

Ditahun 2016 Aryanti melakukan penelitian penerapan fuzzy tsukamoto pada aplikasi enggajian karyawan studi kasus pada persewaan kaset pada matahari rental cell. Aryanti melakukan penelitian atas dasar permasalahan yang terjadi selama menggunakan system penggajian manual. Ada tiga kriteria yang digunakan yaitu jam masuk, jam pulang, dan bonus. Tiap tiap kategori dibuat aturan yaitu disiplin, lamban, naik dan turun. Berdasarkan penelitian yang dilakukan oleh Aryanti, dapat diketahui hasil bahwa penerapan fuzzy tsukamoto pada aplikasi mampu memudahkan bagi perusahaan dalam pengambilan keputusan untuk bonus karyawan [4].

Kemudian di tahun 2015 onibala dan kawankawan membuat perancangan radio frequency identification (RFID) untuk system absensi berbasis mikrokontroller ATmega 8535. Alat dan bahan yang digunakan meliputi RFID Reader, DT-AVR Low Cost Micro System Mikrokontroler ATMega 8535, DI-Smart LCD 2x16, USB to RS232, Papan PCB, Kabel pita, Mur dan baut, Downloader, DB9 Male, Led, Buzzer dan kapasitor, Max 232. Dari penelitian ini, system absensi ini berhasil di jalankan dengan cara menempelkan rfid tag ke rfid reader dengan jarak $<=4 \mathrm{~cm}$. penelitian ini juga berhasil memudahkan dalam system absensi dan mempersingkat waktu pada saat melakukan absensi dengan tingkat kesuksesan tag $100 \%$ [5].
RFID telah berkembang pesat dalam beberapa dekade terakhir seiring dengan permintaan dari industri modern di mana akurasi data diperlukan dan peningkatan efisiensi suatu sistem, pendukung komponen peralatan elektronik ini adalah pembaca RFID dan Tag RFID, di mana banyak jenis tag telah diproduksi sesuai dengan kebutuhan industri. Teknologi ini telah diterapkan pada berbagai sektor seperti industry, bandara, dan system pemantauan kehadiran [6].

\subsection{Fuzzy Mamdani}

Fuzzy Inference System merupakan sebuah kerangka kerja perhitungan berdasarkan konsep teori himpunan fuzzy dan pemikiran fuzzy yang digunakan dalam penarikan kesimpulan atau suatu keputusan (Kusumadewi, 2006). Fuzzy mamdani ini menghasilkan output berupa suatu nilai pada domain himpunan fuzzy yang dikategorikan ke dalam komponen linguistik. Metode Fuzzy Mamdani merupakan salah satu bagian dari Fuzzy Inference System yang berguna untuk penarikan kesimpulan atau suatu keputusan terbaik dalam permasalahan yang tidak pasti (Bova, 2010). Metode Fuzzy Mamdani diperkenalkan oleh Ebrahim Mamdani pada tahun 1975. Metode Fuzzy Mamdani dalam prosesnya menggunakan kaedah-kaedah linguistik dan memiliki algoritma fuzzy yang dapat dianalisis secara matematika, sehingga lebih mudah dipahami (McNeill, 1994) [7].

\subsection{Radio Frequency Identification (RFID)}

Radio Frequency Identification (RFID) Adalah teknologi penangkapan data yang dapat digunakan secara elektronik untuk mengidentifikasi, melacak dan menyimpan informasi yang sebelumnya tersimpan dalam id tag dengan menggunakan gelombang radio. RFID adalah sebuah metode identifikasi secara otomatis dengan menggunakan suatu piranti yang disebut RFID tag atau transporder. Data yang ditransmisikan dapat berupa kode-kode yang bertujuan untuk mengidentifikasi suatu objek tertentu. Pada RFID proses identifikasi dilakukan oleh RFID reader dan RFID tag. RFID tag diletakkan pada suatu benda atau objek yang akan diidentifikasi. Tiap-tiap RFID tag memiliki data angka identifikasi (ID number) yang unik, sehingga tidak ada RFID tag yang memiliki ID number yang sama[8].

\subsection{NodeMcu}

Modul WiFi NodeMCU adalah firmware interaktif berbasis LUA Espressif ESP8622 Wifi SoC. NodeMCU ESP8266 memiliki 4MB flash, 11 pin GPIO dimana 10 diantaranya dapat digunakan untuk PWM, 1 pin ADC, 2 pasang UART, WiFi $2,4 \mathrm{GHz}$ serta mendukung WPA/ WPA2 [10]. NodeMCU selain dapat diprogram menggunakan bahasa LUA dapat juga diprogram menggunakan bahasa $\mathrm{C}$ menggunakan arduino IDE[9]. 


\section{METODE PENELITIAN}

\subsection{Desain Arsitektur Sistem}

dalam desain arsitektur sistem terdapat tiga tahap yaitu input, proses, dan output seperti yang ada di gambar 1 di bawah ini

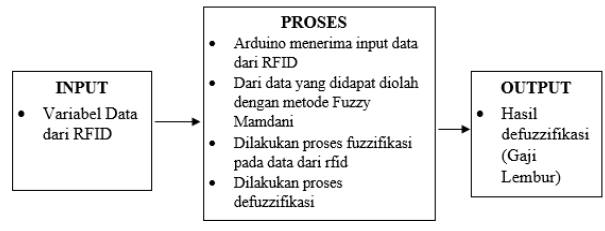

Gambar 1 Arsitektur sistem

\subsection{Desain Rangkaian}

Perangkat yang digunakan meliputi NodeMcu V3, RFID RC522, dan LCD I2C 16 X 2

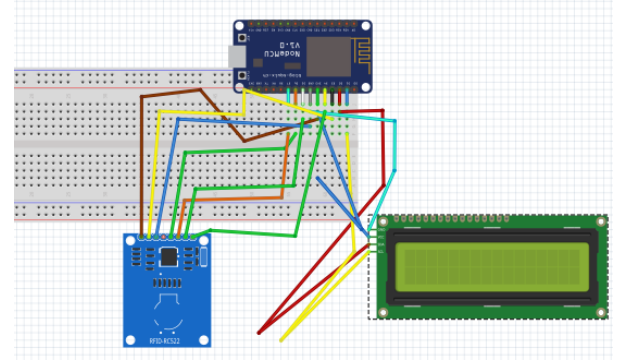

Gambar 2 Desain Rangkaian

\subsection{Flowchart Sistem}

Flowchart sistem ini menjelaskan proses berjalananya aplikasi seperti ditunjukkan pada Gambar 3.

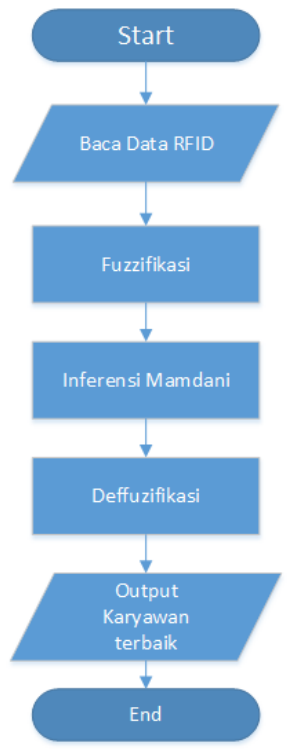

Gambar 3 Flowchart Sistem

Berdasarkan flowchart pada Gambar 3, sistem dimulai dari user melakukan tapping kartu rfid kemudian seistem membaca data rfid dan di simpan kedalam database. Dari data tersebut kemudian di proses menggunakan metode fuzzy Mamdani, output dari data tersebut nanti akan diperoleh karyawan terbaik setelah di defuzzifikasi.

\section{HASIL DAN PEMBAHASAN}

\subsection{Pengujian Hardware}

Pengujian komponen dari Alat yang sudah terkoneksi meliputi RFID RC522, NodeMcu Esp 8266 V3, LCD $16 \times 2$, perangkat RFID dan NodeMcu sudah berhasil terkoneksi dengan database sehingga dapat dilakukan pertukaran data antara database dan NodeMcu

Adapaun implementasi hardware ditunjukkan pada Gambar 4

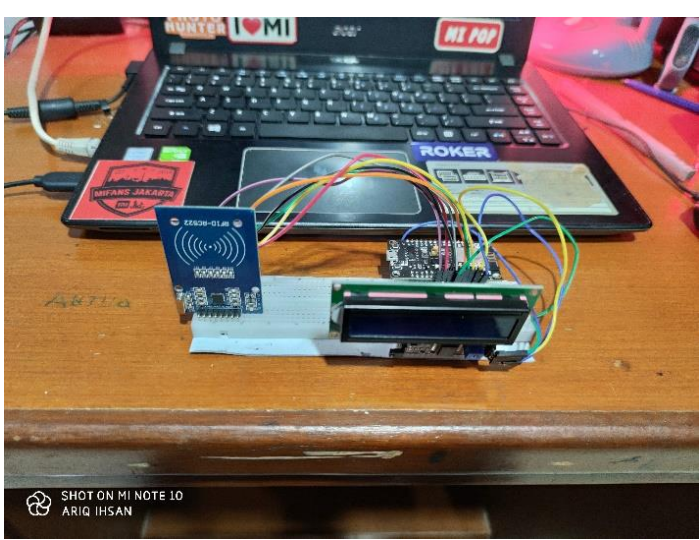

Gambar 4 Implementasi Absensi RFID

Gambar 4 merupakan alat dari absensi RFID yang sudah berhasil terkoneksi dengan database untuk melakukan pertukaran data.

\subsection{Pengujian RFID dan NodeMcu}

Pengujian menggunakan RFID berfungsi untuk mengetahui UID yang terdapat pada kartu rfid. UId yang dihasilkan dari pembacaan sensor ini adalah berupa UID yang masing-masing kartunya memiliki penomoran berbeda. Skema rangkaian alat beserta hasil pengujian sensor Piezoelektrik ditunjukkan pada Gambar 5

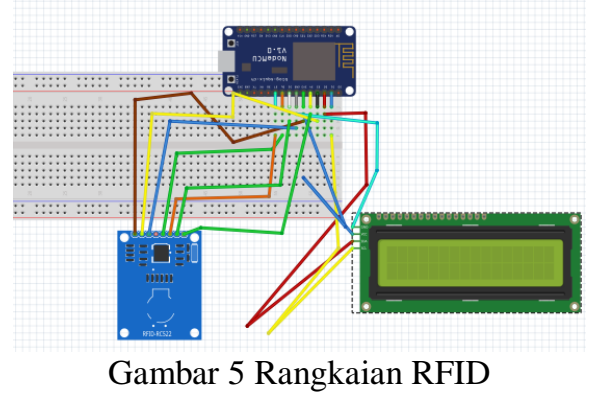

Gambar 5 Merupakan diagram blok atau gambar rangkaian dari rfid reader yang dihubungkan ke NodeMcu menggunakan kabel jumper dan breadboard. Hasil pembacaan RFID dapat dilihat pada gambar 6. 


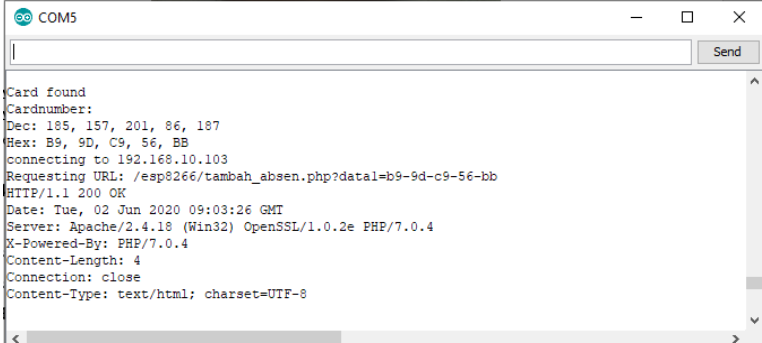

Gambar 6 pengujian baca rfid

Pada gambar 6 menunjukkan pengujian menempelkan kartu rfid ke rfid reader. Dari hasil pengujian diketahui UID dari kartu rfid tersebut adalah b9-9d-c9-56-bb, data uid tersebut kemudian disimpan ke dalam database menggunakan Bahasa pemrograman php ke url esp8266/tambah_absen.php

\subsection{Form Halaman Login}

Pada gambar 7 terdapat form login untuk mengakses data kayawan dan data absensi. Form ini hanya bisa diakses oleh admin dengan memasukkan email dan password.

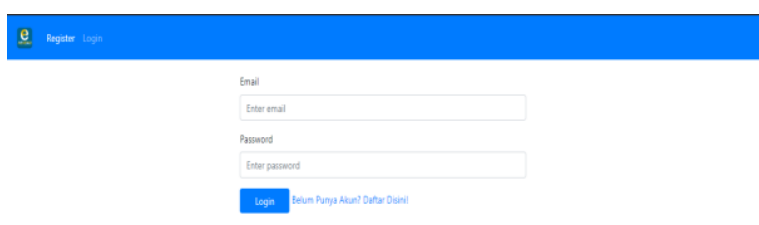

\section{Gambar 7 form login}

Setelah admin melakukan proses login admin akan diarahkan ke halaman dashboard. Dihalaman dashboard ini akan ditampilkan jumlah keseluruhan karyawan, jumlah karyawan yang melakukan absensi masuk perhari, dan jumlah karyawan yang melakukan absensi pulang perhari seperti yang ada pada gambar 8 di bawah.

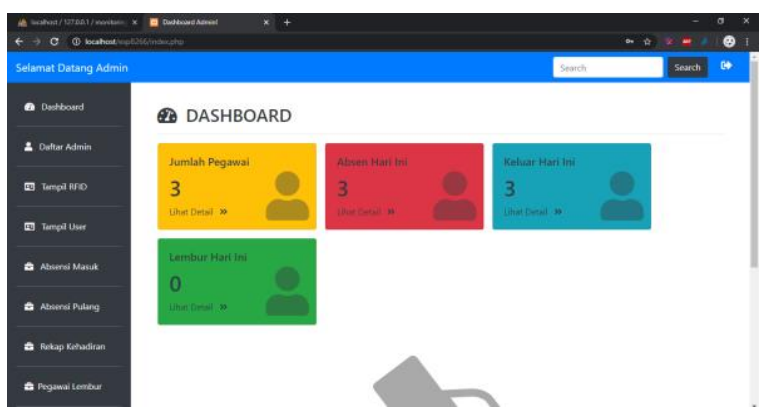

Gambar 8 halaman dashboard

\subsection{Halaman Rekap Absensi}

Pada halaman ini admin dapat melihat rekap absensi karyawan yang sudah melakukan absensi masuk dan pulang menggunakan rfid. Admin dapat melihat sesuai tanggal yang diinginkan dengan cara memilih tanggal yang tersedia dalam halaman, untuk lebih detail dapat dilihat pada gambar 9 .

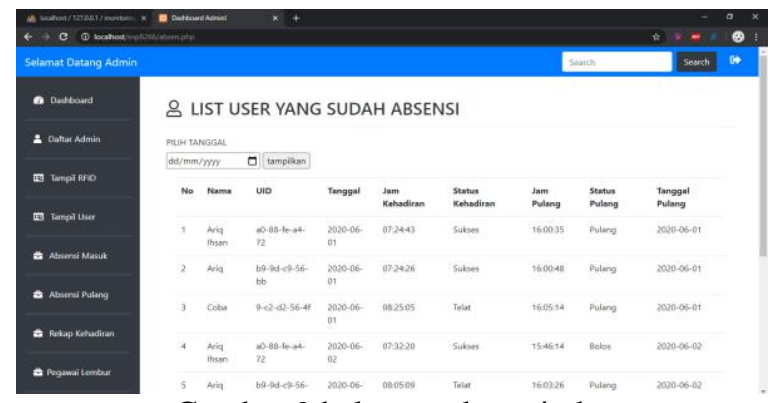

Gambar 9 halaman absensi.php

\subsection{Pengujian Fungsional}

Tabel 1 Pengujian fungsional

\begin{tabular}{|l|c|c|}
\hline \multirow{2}{*}{\multicolumn{1}{|c|}{ Fungsional }} & \multicolumn{2}{c|}{ Berhasil } \\
\cline { 2 - 3 } & Ya & Tidak \\
\hline Form Login Admin & $\checkmark$ & \\
\hline Login & $\checkmark$ & \\
\hline Logout & $\checkmark$ & \\
\hline Tambah Admin & $\checkmark$ & \\
\hline Tambah User & $\checkmark$ & \\
\hline Edit User & $\checkmark$ & \\
\hline Tampil User & $\checkmark$ & \\
\hline Tampil Absensi & $\checkmark$ & \\
\hline Penerapan Karyawan Terbaik & & X \\
\hline Deteksi Kartu & $\checkmark$ & \\
\hline Register Kartu & $\checkmark$ & \\
\hline Absensi Masuk & $\checkmark$ & \\
\hline Absensi Keluar & $\checkmark$ & \\
\hline Absensi Lembur & $\checkmark$ & \\
\hline NodeMcu Koneksi Wifi & $\checkmark$ & \\
\hline
\end{tabular}

Berdasarkan tabel 1 dapat diketahui bahwa semua fungsi dapat berjalan dengan baik $80 \%$ hanya penerapan karyawan terbaik saja yang masih belum bisa berfungsi

Tabel 2 Pengujian hardware

\begin{tabular}{|c|l|c|c|}
\hline \multirow{2}{*}{ No. } & \multicolumn{2}{|c|}{ Aspek Pengujian } & \multicolumn{2}{|c|}{ Berhasil } \\
\cline { 3 - 4 } & & Ya & tidak \\
\hline 1. & Baca uid kartu rfid & $\checkmark$ & \\
\hline 2. & Kirim data uid kartu rfid & $\checkmark$ & \\
\hline 3. & Register uid & $\checkmark$ & \\
\hline 4. & Kirim data absensi masuk & $\checkmark$ & \\
\hline 5. & Kirim data absensi pulang & $\checkmark$ & \\
\hline 6. & Kirim data absensi lembur & $\checkmark$ & \\
\hline
\end{tabular}

Berdasarkan tabel 2 dapat diketahui bahwa semua fungsi pada hardware dapat berjalan dengan baik. 
Tabel 3 Pengujian Presensi

\begin{tabular}{|c|c|c|c|c|c|}
\hline \multirow{2}{*}{ UID } & \multirow{2}{*}{$\begin{array}{c}\text { Aspek } \\
\text { Pengujian }\end{array}$} & \multicolumn{4}{|c|}{ Berhasil } \\
\hline & & Ya & tidak & Waktu & Status \\
\hline \multirow{3}{*}{$\begin{array}{c}9-\mathrm{c} 2-\mathrm{d} 2- \\
56-4 \mathrm{f}\end{array}$} & $\begin{array}{l}\text { Presensi } \\
\text { Masuk }\end{array}$ & $\checkmark$ & & $\begin{array}{c}\text { 2020-06-01 } \\
08: 25: 05\end{array}$ & Telat \\
\hline & $\begin{array}{l}\text { Presensi } \\
\text { Pulang }\end{array}$ & $\checkmark$ & & $\begin{array}{c}2020-06-01 \\
16: 05: 14\end{array}$ & Sesuai \\
\hline & $\begin{array}{l}\text { Presensi } \\
\text { Lembur }\end{array}$ & $\checkmark$ & & $\begin{array}{c}2020-06-01 \\
16: 31: 56\end{array}$ & $\begin{array}{l}\text { Mulai } \\
\text { Lembur }\end{array}$ \\
\hline \multirow{2}{*}{$\begin{array}{c}\text { b9-9d-c9- } \\
56-b b\end{array}$} & $\begin{array}{l}\text { Presensi } \\
\text { Masuk }\end{array}$ & $\checkmark$ & & $\begin{array}{c}2020-06-01 \\
07: 24: 26\end{array}$ & $\begin{array}{l}\text { Tepat } \\
\text { Waktu }\end{array}$ \\
\hline & $\begin{array}{l}\text { Presensi } \\
\text { Pulang }\end{array}$ & $\checkmark$ & & $\begin{array}{c}2020-06-0 \\
16: 00: 48\end{array}$ & Sesuai \\
\hline \multirow{2}{*}{$\begin{array}{c}\mathrm{a} 0-88-\mathrm{fe}- \\
\mathrm{a} 4-72\end{array}$} & $\begin{array}{l}\text { Presensi } \\
\text { Masuk }\end{array}$ & $\checkmark$ & & $\begin{array}{c}2020-06-01 \\
07: 24: 43\end{array}$ & $\begin{array}{c}\text { Tepat } \\
\text { Waktu }\end{array}$ \\
\hline & $\begin{array}{l}\text { Presensi } \\
\text { Pulang }\end{array}$ & $\checkmark$ & & $\begin{array}{c}2020-06-01 \\
16: 00: 35\end{array}$ & Sesuai \\
\hline
\end{tabular}

Dari tabel 3 dapat diketahui bahwa pengujian presensi pada tanggal 01-06-2020 dapat berjalan dengan baik $100 \%$ detail dengan tanggal dan jam yang realtime

Tabel 4. Pengujian Fuzzy Mamdani

\begin{tabular}{|c|c|c|c|c|c|c|}
\hline No & UID & $\begin{array}{c}\text { Berha } \\
\text { sil }\end{array}$ & $\begin{array}{c}\text { Juml } \\
\text { ah } \\
\text { Hadir }\end{array}$ & $\begin{array}{c}\text { Jumlah } \\
\text { Tepat }\end{array}$ & $\begin{array}{c}\text { Hasil } \\
\text { Fuzzifikasi } \\
\text { mamdani }\end{array}$ & $\begin{array}{c}\text { Status } \\
\text { Hasil }\end{array}$ \\
\hline 1. & $\begin{array}{c}\text { a0-88- } \\
\text { fe-a4- } \\
72\end{array}$ & $\checkmark$ & 17 & 15 & 8,36 & $\begin{array}{c}\text { Karyawan } \\
\text { Terbaik }\end{array}$ \\
\hline 2. & $\begin{array}{c}\text { b9-9d- } \\
\text { c9-56- } \\
\text { bb }\end{array}$ & $\checkmark$ & 18 & 16 & 8,91 & $\begin{array}{c}\text { Karyawan } \\
\text { Terbaik }\end{array}$ \\
\hline 3. & $\begin{array}{c}9-\mathrm{c} 2- \\
\mathrm{d} 2-56- \\
4 \mathrm{f}\end{array}$ & $\checkmark$ & 20 & 7 & 0,83 & $\begin{array}{c}\text { Bukan } \\
\text { Karyawan } \\
\text { Terbaik }\end{array}$ \\
\hline
\end{tabular}

Dari tabel 4 dapat diketahui bahwa pengujian fuzzy Mamdani menggunakan metode centroid dapat berjalan dengan baik $100 \%$ sesuai dengan perhitungan manual yang sudah di lakukan dan dapat diketahui bahwa karyawan dengan uid 9-c2-d2-56-4f bukan merupakan karyawan terbaik karena hasil defuzzifikasi tidak lebih dari pada 7

\section{KESIMPULAN DAN SARAN}

\subsection{Kesimpulan}

Berdasarkan beberapa pengujian yang telah dilakukan didapatkan kesimpulan :

1. Hasil dari pengujian fungsional system dapat diketahui bahwa sistem dapat berjalan $80 \%$.

2. Pada hasil pengujian alat dapat membaca dan mengirim uid dari RFID tag ke database $100 \%$

3. Alat dapat mengirimkan data absensi secara realtime ke database sesuai dengan pengujian hardware $100 \%$

4. Dari pengujian presensi system dapat mengolah status kehadiran sesuai dengan waktu presensi

5. pada pengujian presensi system dapat menampilkan pegawai yang melakukan presensi lembur secara realtime

\subsection{Saran}

Berdasarkan penelitian yang telah dilakukan, maka penulis dapat memberikan saran-saran untuk pengembangan selanjutnya antar lain :

1. Menambahkan buzzer sebagai peringatan apabila user berhasil melakukan absensi

2. Memberikan notifikasi berupa sms jika berhasil melakukan absensi kepada pimpinan perusahaan agar lebih memudahkan pimpinan perusahaan dalam memantau absensi kehadiran pegawai.

\section{DAFTAR PUSTAKA}

[1] Aditia MS, B., Julius St, M. and Setyawan, R.A., 2013. Aplikasi RFID untuk Sistem Presensi Mahasiswa di Universitas Brawijaya berbasis Protokol Internet. Jurnal Mahasiswa TEUB, 1(4).

[2] Verdian, I., 2015. Aplikasi Sistem Absensi Mahasiswa Menggunakan Sidik Jari PADA Universitas Putra Indonesia "Yptk" Padang. Komputer Teknologi Informasi, 2(1).

[3] Faruq, A, \& Nuryana, IKD. (2016). Perancangan Sistem Penggajian Guru Menggunakan RFID (Radio Frequency Identification) Studi Kasus : SMA Negeri. Universitas Negeri Surabaya. Jurnal Manajemen Informatika, 5(2).

[4] Vita DA. (2016). Penerapan Fuzzy Tsukamoto pada Aplikasi Penggajian Karyawan (Studi Kasus : persewaan kaset pada matahari rental pare). Universitas Nusantara PGRI Kediri.

[5] Onibala, J., Arie S.M.L, ST.MT, Brave A.S ST.MT . (2015). Perancangan Radio Frequency Identification (RFID) Untuk Sistem Absensi Berbasis Mikrokontroler ATmega 8535. Fakultas Ilmu Komputer, E-Journal Teknik Elektro dan Komputer 5(7).

[6] Irawan, JD., Adriantantri E., Farid A. (2018). RFID and IOT for Attendance Monitoring System. MATEC Web of Conferences 01020 (164).

[7] Febriani N., (2016). Aplikasi Metode Fuzzy Mamdani Dalam Penentuan Status Gizi Dan Kebutuhan Kalori Harian Balita Menggunakan Software Matlab. Universitas Pendidikan Indonesia.

[8] Febri ZA, Deni S M.Kom, Ir Werman K M.Kom, (2017). Implementasi Radio Frequency Identification (RFID) Sebagai Otomasi Pada Smart Home. Fakultas Teknologi Informasi Universitas Andalas, Teknik Komputer Politeknik Negeri Padang.

[9] Wicaksono MF, (2017). Implementasi Modul Wifi Nodemcu Esp8266 Untuk Smart Home.Unikom Bandung, Jurnal Teknik Komputer Unikom Komputika 6(1) 